\title{
RP-UPLC Method Development and Validation for Simultaneous Estimation of Mometasone Furoate and Miconazole Nitrate in Semisolid Dosage Form
}

\author{
Sarathkumar Devaraj ${ }^{1}$, Amuthalakshmi Sivaperuman ${ }^{1 *}$, Nalini Calambur Nagarajan ${ }^{1}$
}

1Department of Pharmaceutical Analysis, C. L. Baid Metha College of Pharmacy, Thorapakkam. Chennai-600097

\begin{abstract}
An innovative, rapid and precise RP-UPLC method was developed and validated as per ICH guidelines for simultaneous estimation of Mometasone furoate (MF), and Miconazole nitrate $(\mathrm{MN})$ in topical dosage form. Chromatographic separation was carried out using Agilent $\mathrm{C}_{18}(4.6 \mathrm{~mm} \times 100 \mathrm{~mm}, 5 \mu \mathrm{m})$ column and mobile phase consists of $0.1 \% \mathrm{v} / \mathrm{v}$ triethylamine: methanol: acetonitrile (40:30:30 V/V/V; $\mathrm{pH} 3.5)$. The flow rate was $0.6 \mathrm{~mL} / \mathrm{min}$ and detection was set at $235 \mathrm{~nm}$ in UV detector. Retention time of MF and MN were $0.59 \mathrm{~min}$ and $1.13 \mathrm{~min}$ respectively. The method shows good linearity over the concentration range of $10-30 \mu \mathrm{g} / \mathrm{mL} \mathrm{MF}$ and 200-600 $\mu \mathrm{g} /$ $\mathrm{ml} \mathrm{MN}$. Recovery for both analytes was found to be $99.58 \%$ and $98.51 \%$ respectively. LOD and LOQ for MF and MN were found as 5.452 and $0.501 \mu \mathrm{g} / \mathrm{ml}, 1.485$ and $1.20 \mu \mathrm{g} / \mathrm{ml}$ respectively. This newly developed RP-UPLC method can be successfully applied for simultaneous determination of $\mathrm{MF}$ and $\mathrm{MN}$ in topical dosage form.
\end{abstract}

Keywords: Mometasone furoate (MF), Miconazole nitrate (MN), RP-UPLC, LOD, LOQ

\section{INTRODUCTION}

Mometasone furoate (MF) is a topical glucocorticoid and chemically $9 a$, 21-dichloro-11 $\beta$, 17dihydroxy-16 $\alpha$-methylpregna-1-4-diene-17yl furan-2-carboxylate (Figure1). It possesses anti-inflammatory and anti-proliferative activity. It is also used for treatment of skin diseases like dermatitis, psoriasis. It acts by the simulation of phospholipase A2 inhibitory protein and biosynthesis

\footnotetext{
*Corresponding Author: Amuthalakshmi Sivaperuman, e-mail: amuthaaris@gmail.com Sarathkumar Devaraj ORCID Number: 0000-0003-2296-3118

Amuthalakshmi Sivaperuman ORCID Number: 0000-0001-9117-1478

Nalini Calambur Nagarajan ORCID Number: 0000-0002-3960-3154

(Received 16 November 2019, accepted 28 November 2019)
} 
of potent mediators of inflammation such as prostaglandins, leukotrienes. ${ }^{1} \mathrm{Mi}-$ conazole nitrate $(\mathrm{MN})$ is an antifungal agent and an imidazole synthetic derivative. It is chemically known as ((RS)-1-[2-(2,4-Dichloro-benzyloxy)-2-(2,4dichloro-phenyl)-ethyl]-1H-imidazole (Figure 2). It is commonly applied to the skin and also in mucous membrane for the treatment of fungal infective disorder. It works by inhibiting the cytochrome $\mathrm{P} 450$ complex and bio synthesis of ergo sterol in fungal cell membrane. It has a powerful activity against candida albicans and dermatophytes as well as Gram-positive bacteria. ${ }^{2}$

The literature study reveals that there are numerous analytical methods reported for quantification of MF and MN. The study includesUVspectrophotometry $^{3-7}$, TLC $^{8}$, HPTLC ${ }^{9-11,13}$ and HPLC ${ }^{11-30}$. However, no methods were reported in UPLC till now.

Ultra Performance Liquid Chromatography a special version of HPLC with the advantage of technological strides led to a very significant increase in resolution, sensitivity and efficiency with faster results. The intrinsic worth of the method in terms of very low solvent consumption, more robust method with greater confidence, substantial cost reduction makes the technology environment friendly. The aim of the present work is to develop a simple UPLC method with better resolution and to quantify the drug with a short retention time in the selected dosage form.

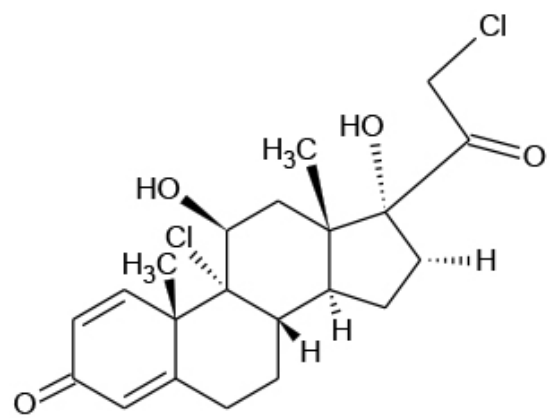

Figure 1. Structure of Mometasone furoate 


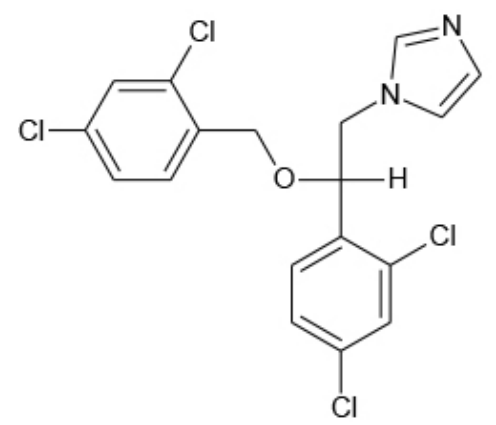

Figure 2. Structure of Miconazole nitrate

\section{METHODOLOGY}

\section{Materials}

Reference standard of Mometasone furoate and Miconazole nitrate gift sample provided from Synthiya research lab private limited, Pondicherry. Cream formulation (Each gm. of ELICA-M cream contains $0.1 \%$ of MF and $2 \% \mathrm{MN}$ ) were purchased from the local pharmacy in Chennai. HPLC grade acetonitrile, methanol, and triethylamine, ortho phosphoric acid and water were purchased from Merck.

\section{UPLC instrumentation and chromatographic condition}

Chromatographic separation was carried out in Agilent $\mathrm{C}_{18}(4.6 \mathrm{~mm} \times 100 \mathrm{~mm}$, $5 \mu \mathrm{m})$ column. Isocratic elution of mobile phase consists of buffer $0.1 \% \mathrm{v} / \mathrm{v}$ of triethylamine: Acetonitrile: methanol in the ratio of 40:30:30 ( $\left.\mathrm{pH}_{3} .5\right)$ by ortho phosphoric acid. Data acquisition and processing was performed using open lab CHEMSTATION software in UPLC Agilent technology-1200 infinity series with high speed auto sampler. The flow rate was $0.6 \mathrm{ml} / \mathrm{min}$ with injection volume of $5 \mu \mathrm{l}$. The column temperature was maintained at ambient condition throughout the separation process. Mobile phase was freshly prepared and filtered through $0.45 \mu$ nylon filter.

\section{Preparation of buffer}

Buffer was prepared by dissolving $1 \mathrm{ml}$ of triethylamine in $1000 \mathrm{~mL}$ distilled water. $\mathrm{pH}$ was adjusted to 3.5 with ortho phosphoric acid and solution was filtered through $0.45 \mu$ nylon filter.

\section{Preparation standard solution}

\section{Standard stock preparation}

Stock was prepared by $20 \mathrm{mg}$ of $\mathrm{MF}(400 \mu \mathrm{g} / \mathrm{mL})$ transferred in $50 \mathrm{ml}$ volumetric flask and dissolved in diluent (mobile phase). 


\section{Standard preparation}

Weigh accurately about $40 \mathrm{mg} \mathrm{MN}$ transferred in $100 \mathrm{ml}$ volumetric flask and add $50 \mathrm{ml}$ of mobile phase sonication for $5 \mathrm{~min}$ and add $5 \mathrm{ml}$ standard stock preparation and volume make up with same. The final concentration was of $20 \mu \mathrm{g} / \mathrm{ml}$ of $\mathrm{MF}$ and $400 \mu \mathrm{g} / \mathrm{ml}$ of $\mathrm{MN}$.

\section{Sample preparation}

Weigh accurately about $1 \mathrm{~g}$ sample (1 mg of MFand20 mg of MN) transferred into $50 \mathrm{~mL}$ volumetric flask. About $30 \mathrm{~mL}$ of mobile phase was added to this volumetric flask and diluted to $50 \mathrm{~mL}$ and sonicated in an ultrasonic bath for 15 min. The solution was filtered through $0.45 \mu \mathrm{m}$ nylon syringe filter.

\section{RESULTS AND DISCUSSION}

\section{Method development}

Literature survey reveals that there are only three HPLC methods are reported for the simultaneous estimation of MF and MN in creams. Khushali Shah and co workers ${ }^{15}$ reported the simultaneous determination by both RP-HPLC and HPTLC of MF and MN. The total runtime of the method was $14 \mathrm{~min}$ and also the retention time was too long $(8.1,4.2 \mathrm{~min})$. In the same way Ramzia IE and co authors ${ }^{14}$ indicated that the RP-HPLC a method which was comparatively lengthy (12 $\mathrm{min}$ ) than the developed UPLC method. Also, the mobile phaseused $5 \% \mathrm{w} / \mathrm{v}$ aqueous ammonium acetate buffer, $\mathrm{pH} 7.6$ and acetonitrile used doesn't showed good resolution. Similarly, the El-Bagary et al., ${ }^{13}$ also showed the simultaneous determination with the run time of 10 min and maximum retention time with 2.08, 5.7 min.

Hence, the present research work was intended to optimize chromatographic condition, for the proposed study. Various mobile phase composition and $\mathrm{pH}$ condition were altered during the trial studies. The mobile phase composition of phosphate buffer of $\mathrm{pH} 6.8$ and methanol (60:40) was tried but this resulted in delayed elution of MN. Again, in the second trial (ammonium acetate buffer pH 4.5 acetonitrile (70:30)) the outcome was peak with tailing factor and resolution was poor for both analytes. After various combinations trials, finally we tried with mobile phase composition $0.1 \%$ v/v triethylamine: Methanol: Acetonitrile (40:30:30) resulted good peak shape and better resolution. Moreover, it was observed during the study that the triethylamine reduced the tailing factor in the chromatogram. So, this combination was fixed as a mobile phase for the development of chromatogram. 


\section{Method validation}

The method was validated as per ICH Q2 (R1) ${ }^{31}$ and the following parameters were considered: system suitability, accuracy, precision, robustness, specificity, linearity, LOD and LOQ.

\section{System suitability}

System suitability was performed by six replicate injection of standard solution with the concentration of $20 \mu \mathrm{g} / \mathrm{mL}$ of $\mathrm{MF}$ and $400 \mu \mathrm{g} / \mathrm{mL}$ of $\mathrm{MN}$ was injected. The parameters like retention time, theoretical plate, resolution and peak area are shown in the Table 1 and Figure 3.

\section{Specificity}

Specificity is the ability to check clearly the analyte in the presence of components which may expect to be present. Typically, these might include impurities, degradant and matrix. There was no interference from excipient and other component with the drug peak. So, the developed method has been found to be specific (Figure 4).

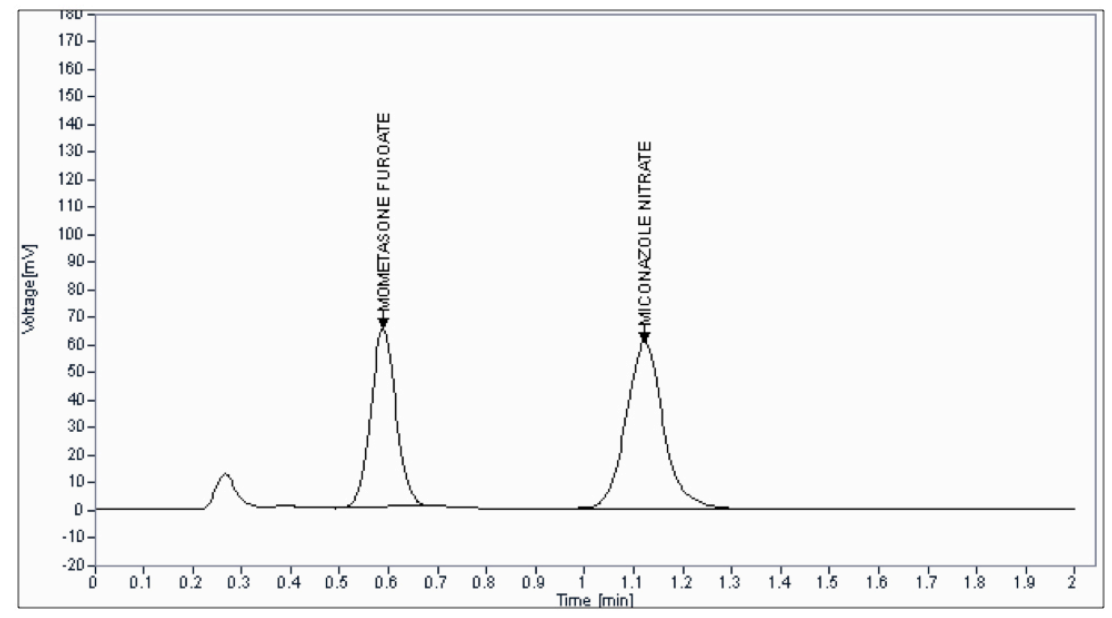

Figure 3. UPLC chromatogram of Mometasone furoate and Miconazole nitrate 
Table 1. Results of system suitability

\begin{tabular}{|c|l|l|l|}
\hline S.NO & \multicolumn{1}{|c|}{ Parameter } & \multicolumn{1}{c|}{ MF } & \multicolumn{1}{c|}{ MN } \\
\hline $\mathbf{1}$ & $\mathrm{R}_{\mathrm{t}}$ & 0.59 & 1.13 \\
\hline $\mathbf{2}$ & Theoretical plates & 6003.22 & 10045.34 \\
\hline $\mathbf{3}$ & Tailing factors & 1.07 & 1.05 \\
\hline $\mathbf{4}$ & SD & 0.94 & 0.63 \\
\hline $\mathbf{5}$ & $\%$ RSD & 0.42 & 0.23 \\
\hline $\mathbf{6}$ & Resolution & 4.7836 & \\
\hline
\end{tabular}

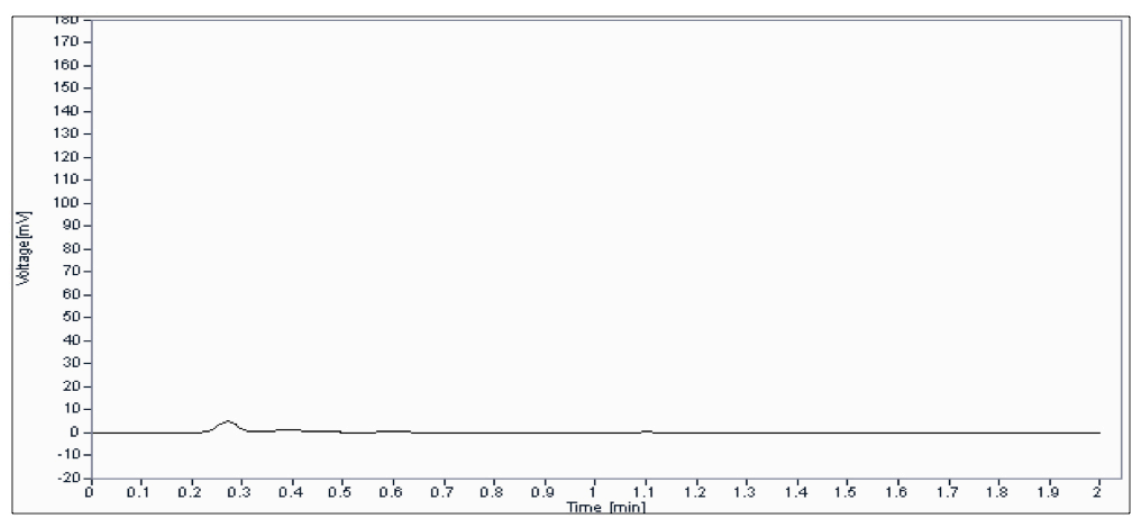

Figure 4. Specificity chromatogram of Mometasone furoate and Miconazole nitrate

\section{Linearity}

The linearity of the method was performed by preparing the concentration range of 9.95-29.84 $\mu \mathrm{g} / \mathrm{mL}$ and $198.57-595.71 \mu \mathrm{g} / \mathrm{mL}$ for $\mathrm{MF}, \mathrm{MN}$, from standard stock solution. Calibration curves were constructed by plotting concentration versus area of MF and MN. The results are shown in Figure 5 and 6. 


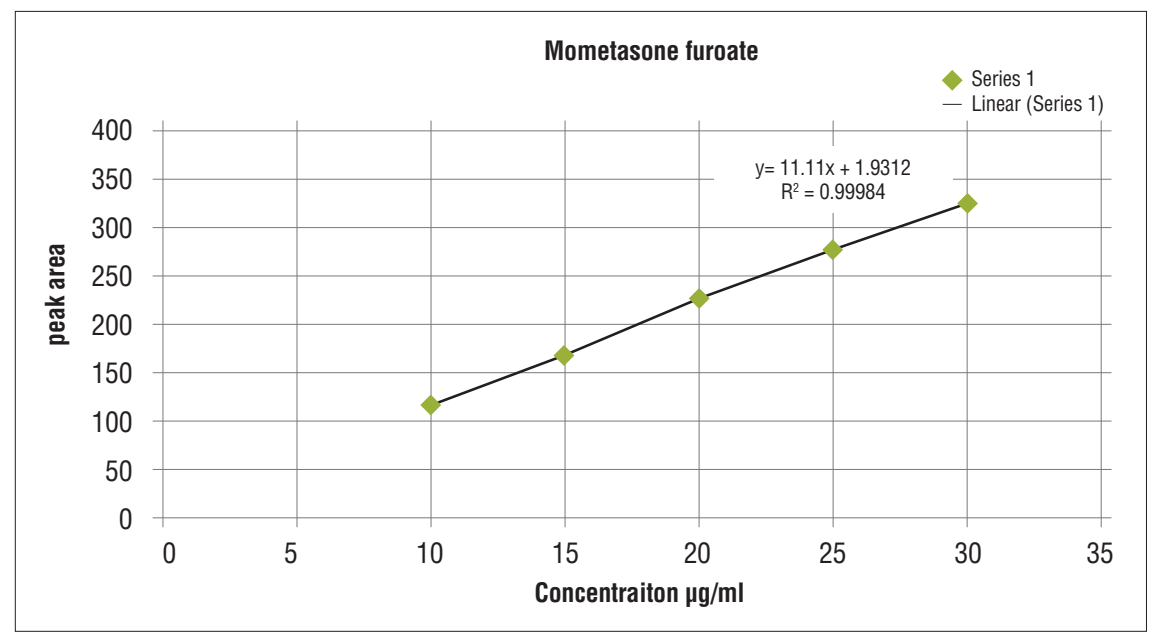

Figure 5. Calibration curve of Mometasone furoate.

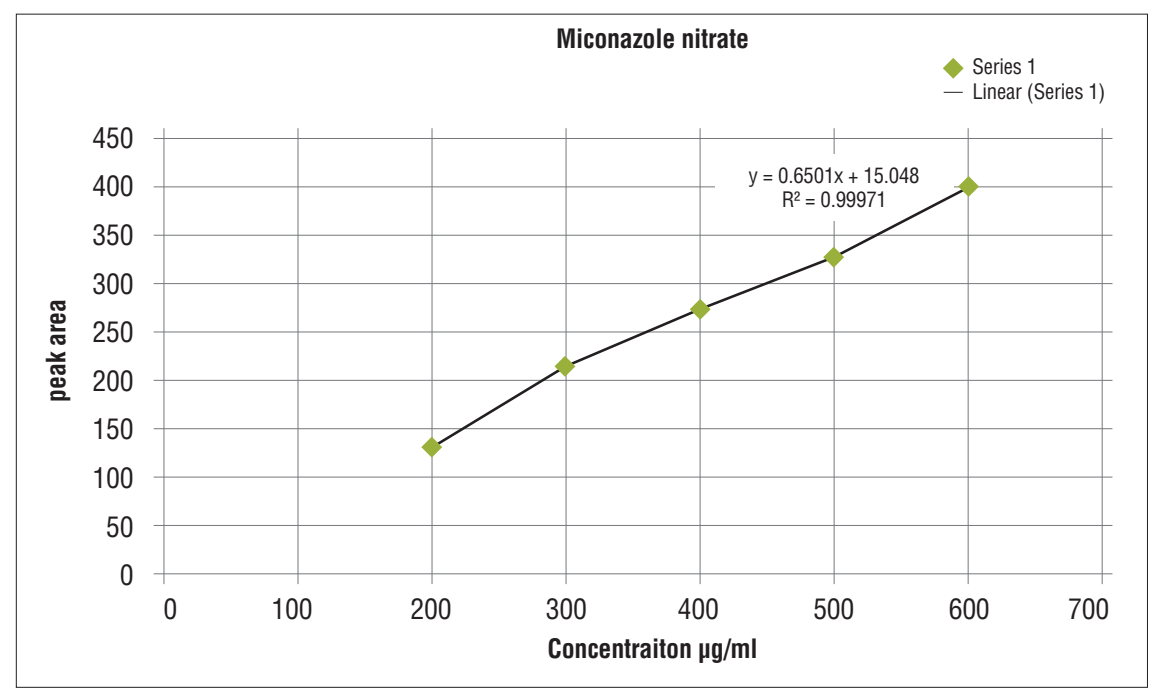

Figure 6. Calibration curve of Miconazole nitrate

\section{Recovery}

The concentration of standard solution of $\mathrm{MF}$ and $\mathrm{MN}$ comprising $0.107 \mathrm{mg} /$ $\mathrm{mL}, 1.968 \mathrm{mg} / \mathrm{mL}$ ando.212mg /mL, $3.888 \mathrm{mg} / \mathrm{mL}$ and $0.314 \mathrm{mg} / \mathrm{mL}, 5.748$ $\mathrm{mg} / \mathrm{mL}$ which represents $10 \%, 20 \%, 30 \%$ level) was injected to LC and recovery was measured to the pre analyzed sample solution.

The recovery mean percentage of $\mathrm{MF}$ and $\mathrm{MN}$ are 99.58 and 99.51 respectively and these results are within the reference limit of 90-110 \%. The \% RSD for MFand $\mathrm{MN}$ is $0.50,0.33$ respectively \% RSD is within the reference limits $\leq 2$. Hence proposed method is accurate. 


\section{Accuracy}

The accuracy was calculated by the analysis of cream and standard at low, mediumand high concentration level. The accuracy was estimated from three replicate injections and calculated as the $\mu \mathrm{g} / \mathrm{mL}$ drug recovered from the drug matrix. The method is found to be accurate and results are summarized in table 2.

Table 2. Accuracy data results of the UPLC method

\begin{tabular}{|c|c|c|c|c|c|}
\hline \multirow{2}{*}{ S.NO } & \multirow{2}{*}{ Sample ID } & \multicolumn{2}{|c|}{ MF } & \multicolumn{2}{c|}{ MN } \\
\cline { 3 - 6 } & & In $\mathbf{~ g}$ & In $\%$ & In $\mathbf{~ g}$ & In $\%$ \\
\hline $\mathbf{1}$ & LOW-SPL-1 & 0.990 & 99.00 & 19.953 & 99.77 \\
\hline & LOW-SPL-2 & 0.990 & 99.00 & 19.948 & 99.74 \\
\hline & LOW-SPL-3 & 0.990 & 99.00 & 19.957 & 99.79 \\
\hline $\mathbf{2}$ & MID-SPL-1 & 1.001 & 100.10 & 19.944 & 99.72 \\
\hline & MID-SPL-2 & 1.000 & 100.00 & 19.919 & 99.60 \\
\hline & MID-SPL-3 & 1.000 & 100.00 & 19.926 & 99.63 \\
\hline $\mathbf{3}$ & HIGH-SPL-1 & 1.002 & 100.20 & 19.749 & 98.75 \\
\hline & HIGH-SPL-2 & 1.007 & 100.70 & 19.830 & 99.15 \\
\hline & HIGH-SPL-3 & 1.003 & 100.30 & 19.769 & 98.85 \\
\hline $\mathbf{4}$ & AVERAGE & 1.00 & 99.81 & 19.888 & 99.44 \\
\hline $\mathbf{5}$ & SD & 0.01 & 0.64 & 0.08 & 0.41 \\
\hline $\mathbf{6}$ & $\%$ RSD & 1.00 & 0.64 & 0.42 & 0.41 \\
\hline
\end{tabular}

Precision

The precision of the proposed assay method was assessed by analyzing standard and sample solution of $20 \mu \mathrm{g} / \mathrm{mL}$ of $\mathrm{MF}$ and $400 \mu \mathrm{g} / \mathrm{mL}$ of $\mathrm{MN}$ in six replicates in intraday and interday precision. The precision of test method results aredisplayed in Table 3 . 
Table 3. Data of Intraday precision and Interday precision

\begin{tabular}{|c|c|c|c|c|c|c|c|c|}
\hline \multicolumn{4}{|c|}{ INTRADAY PRECISION } & \multicolumn{3}{c|}{ INTERDAY PRECISION } \\
\hline \multicolumn{3}{|c|}{ MF } & \multicolumn{2}{c|}{ MN } & \multicolumn{2}{c|}{ MF } & \multicolumn{2}{c|}{ MN } \\
\hline Injection & $\begin{array}{c}\text { Peak } \\
\text { area }\end{array}$ & Assay\% & $\begin{array}{c}\text { Peak } \\
\text { area }\end{array}$ & Assay\% & $\begin{array}{c}\text { Peak } \\
\text { area }\end{array}$ & Assay\% & $\begin{array}{c}\text { Peak } \\
\text { area }\end{array}$ & Assay\% \\
\hline Injection - 1 & 223.56 & 100.30 & 294.665 & 99.64 & 232.292 & 99.70 & 300.904 & 99.11 \\
\hline Injection - 2 & 223.748 & 100.60 & 295.081 & 99.91 & 232.895 & 99.80 & 301.505 & 99.24 \\
\hline Injection - 3 & 223.752 & 100.60 & 295.010 & 99.87 & 232.839 & 99.80 & 301.505 & 99.22 \\
\hline Injection - 4 & 223.464 & 100.50 & 294.762 & 99.85 & 232.626 & 99.60 & 301.507 & 99.11 \\
\hline Injection - 5 & 223.803 & 101.00 & 295.107 & 100.16 & 233.868 & 99.80 & 302.403 & 99.27 \\
\hline Injection - 6 & 223.533 & 101.10 & 295.052 & 100.30 & 234.057 & 99.70 & 302.883 & 99.23 \\
\hline Avg & 223.6433 & 100.38 & 294.9462 & 99.96 & 233.0962 & 99.73 & 301.7845 & 99.20 \\
\hline SD & 0.13 & 0.310 & 0.17 & 0.240 & 0.64 & 0.080 & 0.66 & 0.070 \\
\hline \% RSD & 0.06 & 0.310 & 0.06 & 0.240 & 0.28 & 0.080 & 0.22 & 0.070 \\
\hline
\end{tabular}

\section{Robustness}

The robustness of a method was analysed by changing experimental, chromatographic condition. Altering in flow rate $(0.6 \pm 1 \mathrm{~mL} / \mathrm{min})$, changes in column oven temperature $\left(40 \pm 5{ }^{\circ} \mathrm{C}\right)$, Changes in mobile phase buffer $\mathrm{pH}(3.5 \pm 0.2)$, changes in mobile phase composition and changes in wavelength allowable limits from actual chromatographic condition. It was noted that there was no recognizable change in mean $\mathrm{RT}$ and $\mathrm{RSD}$ and parameters fell within the limit of $\leq 2$. The theoretical plate, tailing factor, resolution was found to be good of MF and MN. This method is robust with variability condition. The analytical condition results are shown in Table 4. 
Table 4. Data of Robustness study

\begin{tabular}{|c|c|c|c|c|c|}
\hline Drug name & \multirow{2}{*}{$\begin{array}{c}\text { Parameter } \\
\begin{array}{c}\text { Flow rate } \\
\text { change } \pm 1 \%\end{array}\end{array}$} & \multicolumn{4}{|c|}{ Chromatographic condition } \\
\hline \multirow{8}{*}{$\begin{array}{l}\text { Mometasone } \\
\text { furoate }\end{array}$} & & RT & AREA & $\begin{array}{l}\text { Theoretical } \\
\text { plate }\end{array}$ & Tailing factor \\
\hline & $0.5 \mathrm{ml} / \mathrm{min}$ & 0.62 & 191.523 & 6005.45 & 1.09 \\
\hline & $0.6 \mathrm{ml} / \mathrm{min}$ & 0.59 & 189.457 & 6003.22 & 1.07 \\
\hline & $0.7 \mathrm{ml} / \mathrm{min}$ & 0.53 & 187.876 & 6007.56 & 1.05 \\
\hline & $\begin{array}{l}\text { Wavelength } \\
\text { change } \pm 2 \%\end{array}$ & & & & \\
\hline & $234 \mathrm{~nm}$ & 0.59 & 189.543 & 6012.23 & 1.04 \\
\hline & $235 \mathrm{~nm}$ & 0.59 & 191.735 & 6005.67 & 1.06 \\
\hline & $236 \mathrm{~nm}$ & 0.59 & 192.567 & 6008.54 & 1.07 \\
\hline \multirow{8}{*}{$\begin{array}{l}\text { Miconazole } \\
\text { nitrate }\end{array}$} & $\begin{array}{c}\text { Flow rate } \\
\text { change } \pm 1 \%\end{array}$ & & & & \\
\hline & $0.5 \mathrm{ml} / \mathrm{min}$ & 1.14 & 274.678 & 10057.76 & 1.10 \\
\hline & $0.6 \mathrm{ml} / \mathrm{min}$ & 1.13 & 277.356 & 10045.34 & 1.05 \\
\hline & $0.7 \mathrm{ml} / \mathrm{min}$ & 0.98 & 271.049 & 10010.58 & 1.03 \\
\hline & $\begin{array}{l}\text { Wavelength } \\
\text { change } \pm 2 \%\end{array}$ & & & & \\
\hline & $234 \mathrm{~nm}$ & 1.12 & 271.812 & 10031.23 & 1.13 \\
\hline & $235 \mathrm{~nm}$ & 1.13 & 276.635 & 10047.56 & 1.06 \\
\hline & $236 \mathrm{~nm}$ & 1.12 & 268.487 & 10067.44 & 1.10 \\
\hline
\end{tabular}

\section{Solution stability}

Stability of sample solution was confirmed by storing it at ambient temperature for $15 \mathrm{hrs}$.The assay of MF and MN were analysed. It was found that percentage labeled amount of MF at 5,10 and 15 were 100.02, 100.07 and 100.12 respectively; Percentage labeled amount of $\mathrm{MN}$ were 5,10,15 were 99.64, 99.73, and 99.88 respectively.

\section{Limit of detection (LOD) and quantification (LOQ)}

The LOD and LOQ were estimated using equation LOD $=3 \times \mathrm{s} / \mathrm{S}$ and LOQ $=10 \times \mathrm{s} / \mathrm{S}$ where $\mathrm{S}=$ standard deviation of $\mathrm{Y}$ intercept $\mathrm{S}=$ average slope of calibration curve. The LOD can be expressed as the minimum level of analyte that produce a considerable reaction. And LOQ was analyzed as the lowest amount of anaytes that was quantified reproducibly. Based on the standard deviation of the response and slope results are presented in table 5 . 
Table 5. $L O Q$ and $L O D$ results of MF and MN

\begin{tabular}{|c|l|l|l|}
\hline \multicolumn{1}{|c|}{ S. No } & \multicolumn{1}{|c|}{ Parameter } & Mometasone Furoate & \multicolumn{1}{c|}{ Miconazole Nitrate } \\
\hline & LOQ $(\mu \mathrm{g} / \mathrm{ml})$ & 1.485 & 1.20 \\
\hline & LOD $(\mu \mathrm{g} / \mathrm{ml})$ & 5.452 & 0.501 \\
\hline
\end{tabular}

The major supremacy of the UPLC method is significant saving in run time. Based on the study reports of the present research work, it is obvious that the developed method also had a very short noticeable reduction in the total run time i.e., only 2 min whereas the literature reported method ${ }^{13,14}$ is tedious which takes around 10-14 min of total run time. In addition, it is a very simple and a novel method in the midst of commercial applicability. The current developed method offers a lot of advantages over the others like speedy acquisition of results, remarkable savings in operational cost and short, sharp retention time with good resolution. Moreover, this UPLC method is found to be accurate and precise. The Validated data by ICH guidelines also confirms the effectiveness of the developed method.

The rapid and economic RP-UPLC method was developed for quantitative analysis of MF and MN in pharmaceutical dosage form which was found to be accurate. The present work done was also precise, linear, robust and specific. The validated results of the current study are additional supporting evidences of the method. This method reveals an admirable performance in terms of speed and sensitive.

\section{ACKNOWLEDGEMENT}

The authors are thankful to Synthiya Research Lab Pvt Ltd., Pondicherry for providing standards and all facilities throughout the research work. The authors sincerely show gratitude to Department of pharmaceutical Analysis, C. L. Baid Metha College of Pharmacy, Thoraipakkam, Chennai, for providing lab facilities and for the constant encouragement during the research work carried out.

\section{CONFLICT OF INTEREST}

The authors declare no conflict of interest for this paper 


\section{REFERENCES}

1. Adcock, I. M.; Ito, K. Principles of Immunopharmacology, $2^{\text {nd }}$ ed.; Frans P. Nijkamp Michael J. Parnham., Eds.; Birkhäuser Basel: Switzerland, 2005; 483-497.

2. Hazen KC, Wu G. Kill power of oral antifungals against dermatophytes. Pediatr Infect Dis. J. 1999; 18, 200-204.

3. Merey, H. A.; El-Mosallamy, S. S.; Hassan, N. Y.; El-Zeany, B. A. Spectrophotometric and Chemometric Study for the Simultaneous Determination of MometasoneFuroate and Miconazole Nitrate in the presence of Pharmaceutical Dosage Form Additive. Anal. Chem. Lett. 2016, $26,70-85$.

4. Ourique, A. F.; Contri, R. V.; Guterres, S. S.; Beck, R. C.; Pohlmann A. R.; Melero, A.; Schaefer, U. F. Set-up of a method using LC-UV to assay Mometasone Furoate in pharmaceutical dosage forms. Quimica Nova. 2012, 35, 818-821.

5. Alizadeh, N.; Ansari, R.; Khaledi, R.N. Extractive spectrophotometric determination of miconazole nitrate in pure and pharmaceutical preparation. J Pharm Health Sci. 2012, 1, 45-52.

6. Wróbel, K.; Wróbel, K.; de la Garza Rodrı́ guez, I. M.; López-de-Alba, P. L; López-Martı́ nez, L. Determination of miconazole in pharmaceutical creams using internal standard and second derivative spectrophotometry. J Pharmaceut Biomed. 1999, 20, 99-105.

7. Parmar, A. P.; Maheshwari, D. Simultaneous Estimation of Mupirocin and MometasoneFuroate in Pharmaceutical Dosage Form by Q-Absorption Ratio Method. Int. Res. J. Pharm. App. Sci. 2015, 5, 1-7.

8. Wulandari, L.; Kiauw Sia, T.; Indrayanto, G. TLC densitometric determination of Mometasone Furoate in topical preparations: Validation. J LiqChromatogrRelat Technol. 2003, 26, 109-117.

9. Patel, K. G.; Shah, P. M.; Shah, P. A.; Gandhi, T. R. Validated high-performance thin-layer chromatographic (HPTLC) method for simultaneous determination of nadifloxacin, Mometasone Furoate, and Miconazole Nitrate cream using fractional factorial design. J. Food Drug Anal. 2016, 24,610-619.

10. Kulkarni, A. A.; Nanda, R. K.; Ranjane, M. N.; Ranjane, P.N. Simultaneous estimation of Nadifloxacin and MometasoneFuroate in topical cream by HPTLC method. Der Pharma Chemica. 2010, 2, 25-30.

11. Pagare, P. K.; Satpute, C. S.; Jadhav, V. M.; Kadam, V. Forced degradation studies and validated stability-indicating HPTLC method for determination of Miconazole Nitrate in soft lozenges. Lib. Der. Pharma Lettr. 2012, 4, 1793-1804.

12. Meshram, D. B.; Bagade, S. B.; Tajne, M. R. Simultaneous determination of Metronidazole and Miconazole Nitrate in gel by HPTLC. Pak. J. Pharm. Sci. 2009, 22, 247-251.

13. El-Bagary, R. I.; Elkady, E. F.; Tammam, M. H.; Elmaaty, A.A. Simultaneous determination of Miconazole and Hydrocortisone or Mometasone using reversed phase liquid chromatography. Eur. J. Chem.2012, 3, 421-425.

14. Ramzia, I. E.; Marwa, A. F.; Manal, A. E.; Enas, H.T. Derivative, derivative of the ratio spectrophotometric and stability-indicating RP-HPLC methods for the determination of mometasonefuroate and miconazole nitrate in cream. J. Chem. Pharm. Res. 2013, 5, 368-378.

15. Khushali Shah, A.; Jayant Dave, B. Development and validation of RP-HPLC and HPTLC methods for simultaneous estimation of mometasonefuroate and miconazole nitrate in creamformulation. W. J. Pharm. Sci. 2015, 4, 1156-1172. 
16. DeZan, M. M.; Cámara, M. S.; Robles, J. C.; Kergaravat, S. V.; Goicoechea, H.C. Development and validation of a simple stability-indicating high-performance liquid chromatographic method for the determination of Miconazole Nitrate in bulk and cream formulations. Talanta. 2009, 79, 762-777.

17. Bîrsan, M.; Cojocaru, I. C.; Scutariu, M. M.; Popovici, I. Validation of a chromatographic method for Miconazole assay from oral sustained release mucoadhesive tablets. Farmacia. 2014, 62, 555-563.

18. Teng, X. W.; Foe, K.; Brown, K. F.; Cutler, D. J.; Davies, N. M. High-performance liquid chromatographic analysis of Mometasone Furoate and its degradation products: Application to in vitro degradation studies. J. Pharmaceut. Biomed. 2001, 26, 313-329.

19. Shaikh, S.; Muneera, M. S.; Thusleem, O. A.; Tahir, M.; Kondaguli, A. V. A simple RP-HPLC method for the simultaneous quantitation of chlorocresol, mometasonefuroate, and fusidic acid in creams. J. Chromatogr. Sci. 2009, 47, 178-183.

20. Shaikh, K. A.; Patil, A. T. Stability-indicating HPLC method for the determination of Mometasone Furoate, Oxymetazoline, Phenyl ethanol and Benzalkonium chloride in nasal spray solution. J. Food Drug Anal. 2013, 1, 14-21.

21. Youssef, R. M.; Korany, M. A.; Afify, M. A. Development of a stability indicating HPLCDAD method for the simultaneous determination of Mometsone Furoate and Salicylic acid in an ointment matrix. Anal. Methods. 2014, 6, 3410-3419.

22. Merey, H. A.; El-Mosallamy, S. S.; Hassan, N. Y.; El-Zeany, B. A. Spectrophotometric and Chemometric Study for the Simultaneous Determination of MometasoneFuroate and Miconazole Nitrate in the presence of Pharmaceutical Dosage Form Additive. Anal. Chem.Lett. 2016, $6,70-85$.

23. Roy, C.; Chakrabarty, J. Development and validation of a stability-indicating RP-HPLC method for the simultaneous determination of Phenoxyethanol, Methylparaben, Propylparaben, Mometasone Furoate, and Tazarotene in topical pharmaceutical dosage formulation. Sci. Pharm. 2013, 81, 951-68.

24. Roy, C.; Chakrabarty, J. Development and Validation of a Novel Stability Indicating RPUPLC Method for Simultaneous Estimation of Methylparaben, MometasoneFuroate and Eberconazole Nitrate in Combined Topical Pharmaceutical Dosage Form. Chem. Sci. 2014, 3, 159-170.

25. Geetha, M.; Rao, P. V.; Sait, S.; Palvai, S. R. A Validated RP-HPLC Method for Simultaneous Determination of Eberconazole, MometasoneFuroate and Methylparaben. O. J. Chem. 2013, 29, 579-587.

26. Modi, P. B.; Shah, N. J. DOE Approach: A Stability Indicating RP-HPLC Method for Simultaneous Estimation of Methylparaben, Mometasonefuroate and Eberconazole nitrate in Topical Formulations. J. A. Pharm. Sci. 2014, 4, 020-025.

27. Chaudhary, M. M.; Akkamma, H. G.; Sreedhar, C.; Rao Srinivas, T.; Thakur, K. Development and Validation of RP-HPLC Method for Simultaneous Estimation of Terbinafine hydrochloride and MometasoneFuroate in Combined Dosage form. J. Pharm. Res. 2017, 11, 286291.

28. Dayyih, W. A.; Al Saadi, N.; Hamad, M.; Mallah, E.; Matalka, K.; Arafat, T. Development and validation of HPLC method for some azoles in pharmaceutical preparation. IJ Pharm. Sci. Res. 2012, 3, 3686- 3692.

29. Belal, T. S.; Haggag, R. S. Gradient HPLC-DAD stability indicating determination of Mi- 
conazole Nitrate and LidocaineHydrochloride in their combined oral gel dosage form. J. Chromatogr. Sci. 2012, 50, 401-419.

30. Ashutosh Kumar, S.; Debnath, M.; Sravani, G. D.; Singh, M. K. Simultaneous Estimation of MometasoneFuroate and FormoterolFumarate from Pharmaceutical Capsule Formulations by RP-HPLC Using PDA Detector. Int. J. Comput. Sci. Tech. 2017, J101-J104.

31. ICH Harmonized Tripartite. Validation of Analytical Procedures: Text and Methodology. Guideline. 2005, Q2 (R1). 